\title{
Morinda officinalis oligosaccharides alleviate depressive-like behaviors in post-stroke rats via suppressing NLRP3 inflammasome to inhibit hippocampal inflammation
}

Research

Keywords:

Posted Date: June 28th, 2021

DOI: https://doi.org/10.21203/rs.3.rs-308551/v2

License: (1) This work is licensed under a Creative Commons Attribution 4.0 International License. Read Full License

Version of Record: A version of this preprint was published at CNS Neuroscience \& Therapeutics on September 24th, 2021. See the published version at https://doi.org/10.1111/cns.13732. 


\section{Abstract}

The authors have requested that this preprint be withdrawn due to erroneous posting.

\section{Full Text}

The authors have withdrawn this preprint from Research Square. 